\title{
Study Of Spatial Effect Distribution Of Groundwater Quality On Rob Disaster In Semarang City
}

\author{
Dwi Nur Yuliyani, ${ }^{1}$ Thomas Triadi Putranto, ${ }^{2}$ Nur Indah. ${ }^{3}$ \\ Master Program of Environmental Science, School of Postgraduate Studies, Diponegoro University, Semarang \\ Indonesia
}

\begin{abstract}
Semarang City is one of the cities located in the north coast of Java, has characteristics of hilly areas and lowland areas, Semarang City is one of the coastal areas and has a high Rob potential. Subdistricts in Semarang City that are inundated by rob disasters are North Semarang Subdistrict, Ngalian, Tugu, Genuk and Pedurungan. The purpose of this research is 1) mapping of inundation in Semarang City using Geographic Information System (GIS). 2). Knowing the quality of ground water (wells) for public consumption around the coastal area of Semarang City that has been exposed to rob water. 3) Find out how many rob water levels have contaminated the Well. Widespread Distribution Population of Rob in Semarang City. Side technique in this research is Purposive Random sampling. The result of this research is the quality of well water obtained from direct measurement of field. Measurements are made using the Water Quality Checker tool. The measurement parameters include pH, DHL, TDS and Nitrate. The required data is the coastal administration map of Semarang city, and the well water quality parameters of KEPMENKES. Selection and sampling of well water by using stratified random sampling technique. The analysis includes a well water quality test in the rob area. Data collection techniques used questionnaire, observation, and documentation techniques. The measurement parameters include $\mathrm{pH}, \mathrm{DHL}$, TDS, and Nitrate. It can be seen that the worst affected District is Genuk District and the District which is still good quality is Pedurungan District.
\end{abstract}

Keywords: Water Quality, Disaster Rob and Groundwater

\section{INTRODUCTION}

Semarang city is one of the areas located in the north coast of Java. Some coastal cities, such as Semarang has abundant potential as well as the threat of danger that is not small as experienced by other big cities. According to Van Bemmelen who divides the island of Java into 7 physiographical units from south to north, Java Island has alluvial plains in the form of a delta which is the main element of the north coast of Java. With varying topographic topography, ranging from $0.7-348 \mathrm{~m}$ above sea level, it consist hills with a land slope ranging from $0 \%-45 \%$, coastal areas have a slope of $25 \%$, and hill areas reaching a slope of $15-40 \%$. The form of Semarang coastal land is influenced by denudational, volcanic, fluvial, and marine structural process [1]. Rob is the process of rising or descending of sea level position periodically due to the influence of gravity and the attraction of astronomical objects, especially by the moon, sun, and earth (Poerbandono in Syetiawan, 2014: 96) [2]. The explanation is in accordance with the opinion of Dongkers (Dongkers in Danu, 2015: 2) [3] which explains

\footnotetext{
* Corresponding author: dwinuryuliyani@gmail.com
} 1 . that the seawater tidal is a phenomenon of the movement of seawater fluctuations and the periodic rise due to the gravitational force and the attraction force of the moon, the earth and the sun, water on earth. Although the size of the moon is smaller than the sun, but because the distance of the moon to Earth more closely causing the gravity of the moon two times greater than the attraction of the sun in the tidal generation of seawater. The tide itself occurs when waves formed in the middle of the sea due to the gravity of the moon and the sun, are infected when it reaches the coastal area. The water of this couple enters the coastal areas that have a lower elevation or equal to the mean sea level (MSL) and the estuary of the river, resulting in inundation by tides of seawater or often referred to as a rob flood. The height of the robot flood will increase along with the rising sea levels and hurricanes that occur in the area.

Sea tidal flood or called rob is a flood that occurs due to tides of seawater that flooded the area that has a lower altitude than the sea surface. Long puddles can last for days even during the year depending on the saturation 
of the soil. As a result of the global flooding, sea level rise due to global warming (Wirastriya, 2005: 32) as well as land subsidence (Gumilar in Nugraha, 2013: 202)[4], which also has a role in the expansion of the flooded puddle. In the future, the impact of rob pools is predicted to increase with the assumption of sea level rise factor and the decrease in the face of the soil increases constantly. The negative impacts and disadvantages of rob puddle events will be felt by the increasing number of flooded puddles of rob from year to year. An advanced disaster risk management is required in overcoming the problem of flood inundation in the city of Semarang in fast, precise, and efficient. Nevertheless, the process of land subsidence in the coastal area varies from 2 to $25 \mathrm{~cm}$ per year (Diposaptono in Setiya Ramadhany,2012 : 2 ) [5].

The problem of water needs in coastal areas related to the threat of rob floods attracts writers to conduct research on the north coast of Java, especially in Semarang. In addition to the study on water quality issues, the study also examines the adaptation of communities in the fulfillment of water needs. Based on this background, the authors compiled the research as a seminar material ICENIS UNDIP Semarang Year 2018. This study uses a descriptive-quantitative method to reveal how much groundwater quality against robust contamination in Semarang City Coast, the researchers chose the title " Study Of Spatial Effect Distribution Of Groundwater Quality On Rob Disaster In Semarang City"

The purpose of research refers to what things to be achieved in a study. The objectives to be achieved are as follows,

1. Knowing the rob inundation in Semarang City using Geographic Information System (GIS)

2. Knowing the quality of groundwater (wells) for public consumption around the area of Semarang City that has been exposed to rob water.

3. To find out how much water content rob that already contaminate well.

\section{DEFINITION}

\subsection{Rob Disaster}

Rob is a flood whose water comes from sea water. This rob flood is a flood caused by sea water tides, until the tidal water floods the land. this rob flood is also known as flooding inundation. This rob flood will often strike or often occur in areas with lower surface than sea level. Because of the overflowing sea water that reaches the land, the water that floods because of this rob flood has a color that tends to be clearer than the water that in the floods usually (Sunarto in Sudrajat,dkk.2012: 155)

\subsection{Water Quality}

Water quality, ie the nature of water and the content of living things, substances, energy, or other components in the water. Water quality is expressed by several parameters, ie physical parameters [6]

\section{METHODOLOGY}

The method used in this study is a descriptive quantitative method [7]. Quantitative research is a research by obtaining data in the form of numbers or qualitative data that is suspected and descriptive research is research done to know the value of the independent variable, either one variable or more (independent) without making a comparison, or connect with other variables.

\subsection{Population Research}

The population in this study is the location directly affected in the city of Semarang is Tugu District, Ngaliyan District, North Semarang District, Genuk District, and Pedurungan District.

3.2. Sampling Research

Based on that opinion, the researcher uses purposive random sampling technique (Sample Aim). Purposive random sampling is the determination of samples with certain considerations (Sugiyono, 2008: 85). This means that the use of purposive random sampling technique because the research has determined the first sample that will be used for research in accordance with the research objectives of the broad distribution of rob and groundwater quality (wells) in the city of Semarang. The study of this sample is large enough and the nature of the population is relatively homogeneous. With this technique, the population is given the opportunity to be a member of the sample, so that sampling can be representative. This technique is done due to several considerations, namely the distribution of rob by using geospatial and groundwater quality (wells) from the affected area.

\subsection{Research variable}

The object of research, what is the point of attention in a study [8] In this study the authors examine some of the variables that will be used to analyze the writer is as follows.

1. Mapping inundation in Semarang City using Geographic Information System (GIS)

2. Water quality standards exist in Indonesia currently using

- Permenkes RI 2010

- Management and Pollution Control.

3. Good Water Quality

- Physical Conditions (Sutrisno in

Lothywena Cashiro, 2012: 18) [9]

- Terms of Chemistry (Sutrisno in Lothywena Cashiro, 2012: 18 [9]

\subsection{Data}

\section{Primary data}

Primary data is the data obtained by way of direct implementation of spaciousness. From the implementation, it can be obtained the results of research in accordance with the existing in the field of $\mathrm{pH}$, TDS,DHL, and Nitrat (NO3).

2. Secondary data

This secondary data collection is done by cooperating with related institutions. The 
secondary data required in completion of this thesis are:

a. Map of administration in Semarang City

b. Map of disaster-prone District of the Regional Disaster Management Agency in Semarang City.

\section{RESULTS AND DISCUSSION}

c. Statistical Data of Semarang City

\subsection{Results}

\subsubsection{Research Area}

Problems that occur in the field of rob that often flooded the area of residential homes in the city of Semarang because the surface of the ground is always down. This tidal seawater will generally hold water that has been piled up, finally able to break down the dike and inundate the land. The well water samples taken are dug wells and artesian wells. The number of the sample taken is as many as five points of the research area. The sampling is as follows,

Table 4.1. Sampling
Based on the results of research on the Quality of Groundwater on Rob Disaster, Tugu District has $\mathrm{pH}$ value of 7.037 which is still in the standard allowed by KEPMENKES 2010 of $6,5-9,5$. The salinity value of Conductivity is between $2470 \mu \mathrm{mhos} / \mathrm{cm}$ and TDS of $1388 \mathrm{mg} / \mathrm{l}$ which is still in the threshold of the applicable regulation of $1500 \mu \mathrm{mhos} / \mathrm{cm}$. The quality for NO3 Microbiology parameters or Nitrate is $3.1 \mathrm{mg} / \mathrm{l}$ at a maximum limit of $10 \mathrm{mg} / \mathrm{l}$. It can be concluded that the quality of well water in Tugu District can only be used for washing and cannot be used for drinking and cooking. If the well water is still consumed for drinking or cooking, it could be bad for the health of the citizens.

Ngaliyan District has a $\mathrm{pH}$ value of 8,174 which is still in the standard allowed by KEPMENKES 2010 of 6.5 - 9.5. The salinity value of Conductivity is between 800 $(\mu \mathrm{S})$ and TDS is $472 \mathrm{mg} / \mathrm{l}$ of the applicable regulation that of $1500 \mu \mathrm{mhos} / \mathrm{cm}$. The quality for NO3 Microbiological parameters or Nitrate is $3.1 \mathrm{mg} / \mathrm{l}$ at a maximum limit of $10 \mathrm{mg} / \mathrm{l}$. It can be concluded that the well water quality in Ngaliyan District can only be used for washing and cannot

\begin{tabular}{|c|c|c|c|c|c|c|c|c|c|}
\hline NO & $\mathbf{X}$ & $\mathbf{Y}$ & ADDRESS & LOCATION & $\begin{array}{l}\text { h } \\
\text { (water } \\
\text { level) }\end{array}$ & DHL & $\mathbf{P h}$ & TDS & Nitrate \\
\hline 1 & 427684 & 9229475 & $\begin{array}{l}\text { Tapak Tugu Rejo } \\
\text { Street } 04 / 06\end{array}$ & TUGU & $\begin{array}{l}2,5 \\
\text { Meter }\end{array}$ & $\begin{array}{l}2470 \\
(\mu \mathrm{S})\end{array}$ & 7.037 & $\begin{array}{l}1388 \\
\mathrm{mg} / \mathrm{l}\end{array}$ & $3.1 \mathrm{mg} / \mathrm{l}$ \\
\hline 2 & 428692 & 9227928 & $\begin{array}{l}\text { Arumanis Tengah } \\
\text { Street } 04 / 02\end{array}$ & NGALIYAN & $\begin{array}{l}2,8 \\
\text { Meter }\end{array}$ & $\begin{array}{l}800 \\
(\mu S)\end{array}$ & 8.174 & $\begin{array}{l}472 \\
\mathrm{mg} / 1\end{array}$ & $0 \mathrm{mg} / 1$ \\
\hline 3 & 438000 & 9222000 & $\begin{array}{l}\text { Bulu Lor Street no } \\
1\end{array}$ & $\begin{array}{l}\text { NORTH } \\
\text { SEMARANG }\end{array}$ & $\begin{array}{l}1,7 \\
\text { Meter }\end{array}$ & $\begin{array}{l}426 \\
(\mu \mathrm{S})\end{array}$ & 8.41 & $\begin{array}{l}820 \\
\mathrm{mg} / 1\end{array}$ & $2.9 \mathrm{mg} / \mathrm{l}$ \\
\hline 4 & 440000 & 9230000 & $\begin{array}{l}\text { Genuk } \\
\text { Street }\end{array}$ & GENUK & $\begin{array}{l}1,8 \\
\text { Meter }\end{array}$ & $\begin{array}{l}6.370 \\
(\mu S)\end{array}$ & 7.03 & $\begin{array}{l}1186 \\
\mathrm{mg} / \mathrm{l}\end{array}$ & $3.8 \mathrm{mg} / \mathrm{l}$ \\
\hline 5 & 440963 & 9225772 & $\begin{array}{l}\text { Palebon Tengah } \\
\text { Street } 01 / 02\end{array}$ & $\begin{array}{l}\text { PEDURUNGA } \\
\mathrm{N}\end{array}$ & $\begin{array}{l}2,2 \\
\text { Meter }\end{array}$ & $\begin{array}{l}1143 \\
(\mu \mathrm{S})\end{array}$ & 6.845 & $\begin{array}{l}736 \\
\mathrm{mg} / 1\end{array}$ & $0 \mathrm{mg} / \mathrm{l}$ \\
\hline
\end{tabular}

Source: Primary Data Research

Semarang City is located on the coast to make people using artesian wells and dug wells to use PDAM, this is because the level of rob that inundate this area is increasing. In some places, there have been many wells whose water is mixed with rob water. The use of well water has changed, the well water can be used for bathing, washing, cooking and drinking now can only be used for bathing and washing while for drinking and cooking residents of Semarang City prefer to use PDAM water from their own well water. The height of soil in the research area varies from 10 meters to 15 meters above sea level (BAPPEDA).

\subsubsection{Well water quality at the research site}

The condition of well water in North Semarang District mostly has an improper condition of consumption because it looks turbid, even many also water source of the population which have bad smell condition. The quality of well water is obtained from direct measurement in the field. Measurements are made by using the Water Quality Checker. Parameter measurements include $\mathrm{pH}$, TDS, DHL and Nitrat (NO3)

\subsection{Discussion}

be used for drinking and cooking. If the well water is still consumed for drinking or cooking, it could be bad for the health of the citizens.

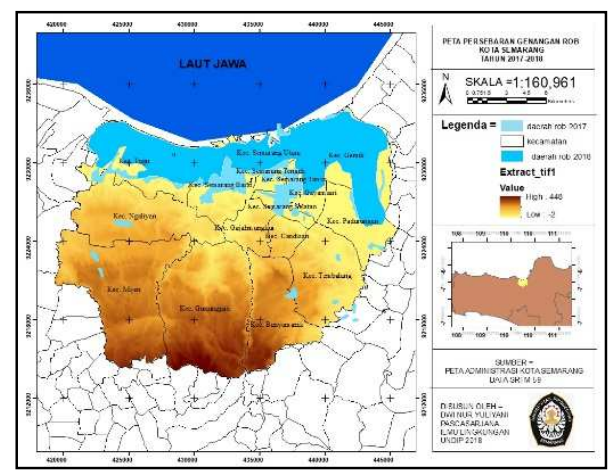

Figure 1. Rob Puddle

Man 2017-2018

North Semarang District has a $\mathrm{pH}$ value of 8.41 which is still in the standard allowed by KEPMENKES 2010 of $6.5-9.5$. The salinity value of Conductivity is between $426(\mu \mathrm{S})$ and TDS of $820 \mathrm{mg} / \mathrm{l}$ of the applicable regulation of $1500 \mu \mathrm{mhos} / \mathrm{cm}$. The quality for NO3 Microbiological parameters or Nitrate of $2.9 \mathrm{mg} / \mathrm{l}$ at a 
maximum limit of $10 \mathrm{mg} / \mathrm{l}$. It can be concluded that the quality of well water in North Semarang District can only be used for washing and cannot be used for drinking and cooking. If the well water is still consumed for drinking or cooking, it could be bad for the health of the citizens. Genuk District has a $\mathrm{pH}$ value of 7.03 which is still in the standard allowed by KEPMENKES 2010 of $6.5-9.5$. The salinity value of Conductivity between $6.370(\mu \mathrm{S})$ and TDS of $1186 \mathrm{mg} / \mathrm{l}$ of the applicable regulation of 1500 $\mu \mathrm{mhos} / \mathrm{cm}$. The quality for NO3 Microbiological parameters or Nitrate is $3.8 \mathrm{mg} / 1$ at a maximum limit of $10 \mathrm{mg} / \mathrm{l}$. It can be concluded that the well water quality in Genuk District is very bad because DHL in Genuk District is the highest. Then it can be seen on Map Distribution of Rob Disaster that Genuk area has a very wide puddle.. Therefore, it can only be used to washing car only.

Pedurungan District has a $\mathrm{pH}$ value of 6,845 which is still in the standard allowed by KEPMENKES 2010 of $6,5-9,5$. The salinity value of Conductivity between 1143 $(\mu \mathrm{S})$ and TDS is $736 \mathrm{mg} / \mathrm{l}$ of the applicable regulation of $1500 \mu \mathrm{mhos} / \mathrm{cm}$. The quality for NO3 Microbiological parameters or Nitrate of $0 \mathrm{mg} / \mathrm{l}$ at a maximum limit of 10 $\mathrm{mg} / \mathrm{l}$. It can be concluded that the quality of well water in Pedurungan District can only be used for washing and cannot be used for drinking and cooking. If the well water is still consumed for drinking or cooking, it could be bad for the health of the citizens. However, Pedurungan District has the best well water quality above the other four districts.

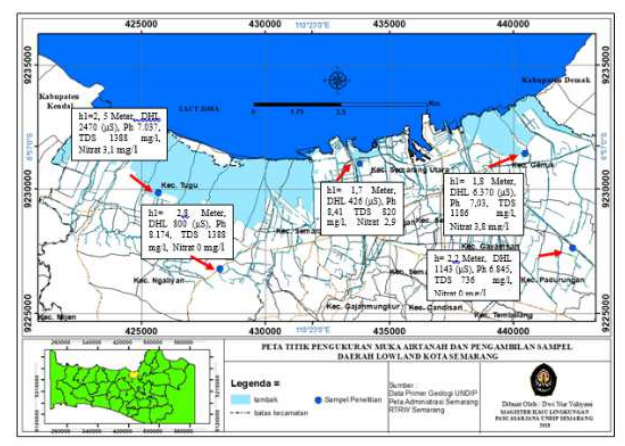

Figure 2. Research map of well water 2018

\section{CONCLUSION}

\subsection{Conclusion}

Research conducted in Semarang City area, with samples of four districts namely Tugu District, Ngaliyan District, North Semarang District, Pedurungan District, and Genuk District can be known from the result and discussion that Semarang City is one of the city that hit by rob disaster, hence the researcher examines the Groundwater Quality Index (Well) which is usually used for daily activities using the Water Quality Checker tool. The measurement parameters include $\mathrm{pH}, \mathrm{DHL}$, TDS, and Nitrate. It can be seen that the worst affected District is Genuk District and the District which is still good quality is Pedurungan District.

\subsection{Suggestion}

Based on the above conclusions, the author can give suggestions as follows:

1. For the government to give socialization about the quality of water in the area affected by rob so that the citizens of Semarang City can distinguish which water is still worth consuming and which water is not feasible consumed.

2. For the public should be able to keep the environment cleanliness of the environment such as not throwing waste in the river

\section{REFERENCES}

1. Marfai, Aries. 2014. Banjir Pesisir Kajian Dinamika Pesisir Semarang. Gadjah Mada University Perss. Jogjakarta

2. Setiyawan, A. 2014. Pengembangan Aplikasi Pengolah Komponen Harmonik Pasut Berbasis Web.Tesis. BIG.Jakarta.

3. Danu, Wijaya Agung. 2015. Rancang Bangun Alat Ukur Gelombang Pasang Surut Jarak Jauh Dengan Memanfaatkan Short Message Services (Sms). Jurnal Fisika. Gravitasi Vol. 15 No. 1. ISSN: 14122375.

4. Nugroho ,S. 2013.Prediksi luas genangan pasang surut (rob) berdasarkan analisis .Jurnal Lingkungan dan Bencana Geologi, Vol. 4 No. 1 April 2013: 71 87.

5. Setiya Ramadhany, Apriliawan. 2012. Daerah Rawan Genangan Rob di Wilayah Semarang Journal Of Marine Research olume 1, Nomor 2, Tahun 2012, Halaman 174-180

6. Effendi, Hefni. 2003. Telaah Kualitas Air Bagi Penggelolaan Sumber Daya danLingkunan Perairan.Kanisius: Yogjakarta.

7. Sugiyono.2011. Metode Penelitian Pendidikan (Pendekatan, Kuantitatif, Kualitatif, dan R\&D). ALFABETA : Bandung.

8. Arikunto, S. 2006. Prosedur penelitian suatu pendekatan praktik. Ed revisi VI. Penerbit PT Rineka Cipta. Jakarta

9. Cashiro, Lothywena. 2013. Pengaruh Air Rob Terhadap Kualitas Air Sumur Di Daerah Pesisir Kota Semarang. Skripsi: UNNES.

10. Bemmelem.H.W.Van.1949. The Geology of Indonesia.Vol II. Economic Geology.

11. Oakley et al, Petter. 1991. The practice of participation in rual development.Geneva. International Labaur office

12. Permenkes RI Nomor 492 Tahun 2010.Persyaratan Kualitas Air Minum.

\section{Acknowledgments :}

Natural disasters can dilate our environment, but it will never harm the heart and spirit of a strong mentor. (dwinuryuliyani) 